\title{
Shrinkage of Dutch clay soil aggregates
}

\section{J. J. B. BRONSWIJK \& J. J. EVERS-VERMEER}

The Winand Staring Centre for Integrated Land, Soil and Water Research, P.O. Box 125, NL $6700 \mathrm{AC}$ Wageningen, Netherlands

Received 19 October 1989; accepted 19 March 1990

\begin{abstract}
Shrinkage processes in clay soils are important because surface subsidence and shrinkage cracks have a large impact on transport processes in these soils and on their use potential. Of seven representative clay soil profiles from the Netherlands, shrinkage characteristics and COLE and PLE values were measured, using undisturbed natural aggregates. It appeared that the course of the shrinkage process upon drying varied strongly from one soil to another, and very often the measured shrinkage characteristics deflected from the theoretical curve. Some Dutch heavy clay soils belong to the strongest swelling and shrinking soils of the world, with volume decreases of aggregates being maximally $49 \%$ between saturation and ovendryness, and maximally $42 \%$ between saturation and a pressure head of $-16000 \mathrm{~cm}$. Potential surface subsidence of a Dutch field soil due to shrinkage is maximally $15 \mathrm{~cm}$. Under Dutch climatic circumstances, in some heavy clay soils, as a result of normal shrinkage, the aggregates remain saturated throughout the whole year. Only inter-aggregate pores like shrinkage cracks, contain air.
\end{abstract}

Keywords: clay soils, shrinkage, swelling, aggregates, drying, COLE, PLE

\section{Introduction}

Clay soils distinguish themselves from other soils by the presence of certain amounts of clay minerals like kaolinite, illite and montmorillonite. Clay minerals occur in plate-shaped crystals. These crystals are build up of small platelets, consisting of silicium oxides and aluminium hydroxides. The thickness of each platelet is about 5-10 $\AA$. The number of platelets within one clay crystal depends on the configuration of the silicium oxides and the aluminium hydroxides in the platelet, but may vary from 1 (Na-montmorillonite) to almost infinite (Kaolinite). Due to the special structure of clay minerals, platelets or packets of platelets are surrounded by water layers (Bolt \& Bruggenwert, 1978). Upon drying, the platelets approach each other (Fig. 1). This process causes shrinkage of soil aggregates. Upon wetting, the distance between the platelets increases again, through which the aggregates regain their original volume. The volume decrease of soil aggregates upon drying can be divided into three shrinkage phases (Haines, 1923): 

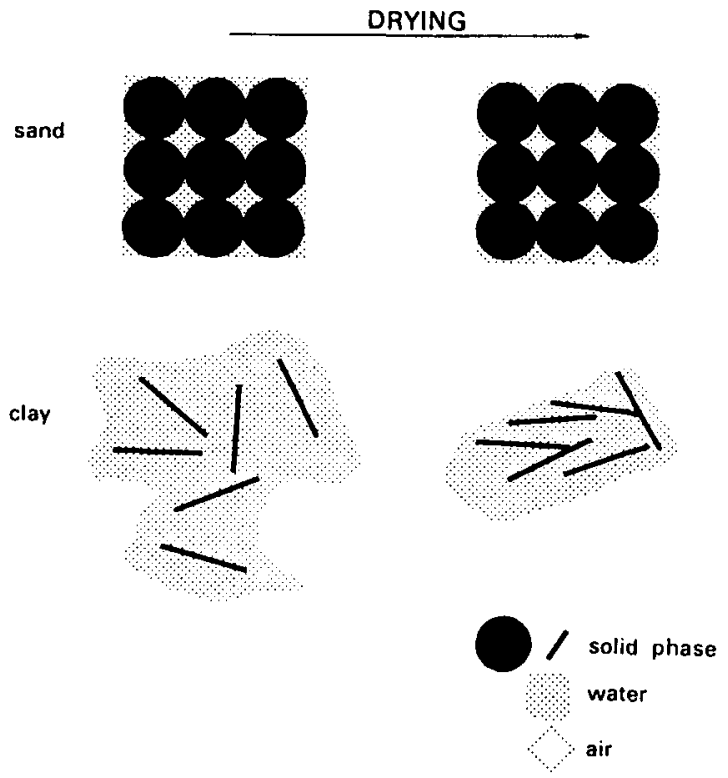

Fig. 1. Schematic representation of the process of drying and air entry in sandy soils and clay soils.

- Normal shrinkage. Volume decrease of clay aggregates is equal to water loss. The aggregates remain fully saturated.

- Residual shrinkage. Upon drying the volume of the aggregates still decreases, but water loss is greater than volume decrease. Air enters the pores of the aggregates.

- Zero shrinkage. The soil particles have reached their densest configuration. Upon further water extraction, the volume of aggregates stays constant. Water loss is equal to increase of air volume in the aggregates.

The three shrinkage phases are pictured schematically in Figure 2.

Course and magnitude of the shrinkage process of soil aggregates upon drying are determined by clay content, clay mineralogy, capacity and composition of the cation exchange complex and organic matter content. (Greene-Kelly, 1974; Schafer \& Singer, 1976; Murray \& Quirk, 1980; Parker et al., 1982; Tessier, 1984).

In large samples, containing more than one structural unit, sometimes a fourth shrinkage phase can be distinguished: structural shrinkage (Stirk, 1954; Yule \& Ritchie, 1980). Structural shrinkage occurs in saturated soils. When saturated soils dry, large water-filled pores may be emptied. Due to this, aggregates can get a somewhat denser packing. Structural shrinkage falls outside the scope of this article because the volume changes in this shrinkage phase are negligible and furthermore the magnitude of this phase is not a soil constant but varies strongly with land use and soil management (Reeve \& Hall, 1978).

In studies on swelling and shrinkage of clay soils, the shrinkage characteristic is 


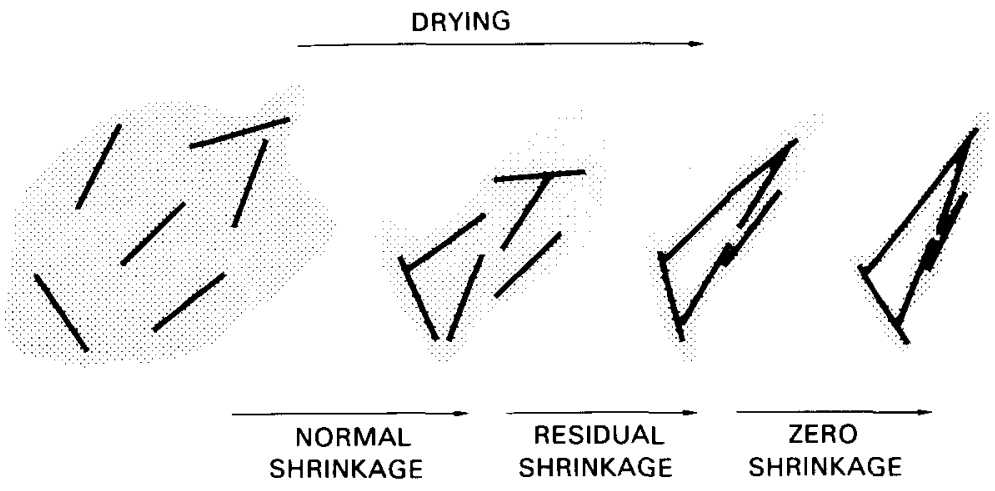

Fig. 2. The three shrinkage phases of clay soil aggregates upon drying.

often used. This characteristic has been defined in many ways but is essentially always the relation between soil volume and soil water content. One of the most-used forms of the shrinkage characteristic is the relation between moisture ratio and void ratio of soil aggregates. Moisture ratio $\vartheta$ and void ratio $e$ are defined as:

$$
\begin{aligned}
& \vartheta=\text { volume of water/volume of solids } \\
& e=\text { volume of pores/volume of solids }
\end{aligned}
$$

Because of volume changes of aggregates, the use of moisture ratio $\vartheta$ and void ratio $e$ is preferred to water content $\theta$ and porosity $\epsilon . \vartheta$ and $e$ can simply be converted into $\theta$ and $\epsilon$ :

$$
\begin{aligned}
& \epsilon=\frac{e}{1+e} \\
& \theta=\frac{\vartheta}{1+e}
\end{aligned}
$$

The general form of the shrinkage characteristic, including the three shrinkage phases, is shown in Figure 3.

The relation between volume and void ratio of soil aggregates is:

$$
V=V_{\mathrm{s}}(1+e)
$$

in which:

$V=$ volume of soil aggregates $\left(\mathrm{m}^{3}\right)$

$V_{\mathrm{s}}=$ volume of solids $\left(\mathrm{m}^{3}\right)$

Any change in void ratio, derived from the shrinkage characteristic, can simply be Netherlands Journal of Agricultural Science 38 (1990) 


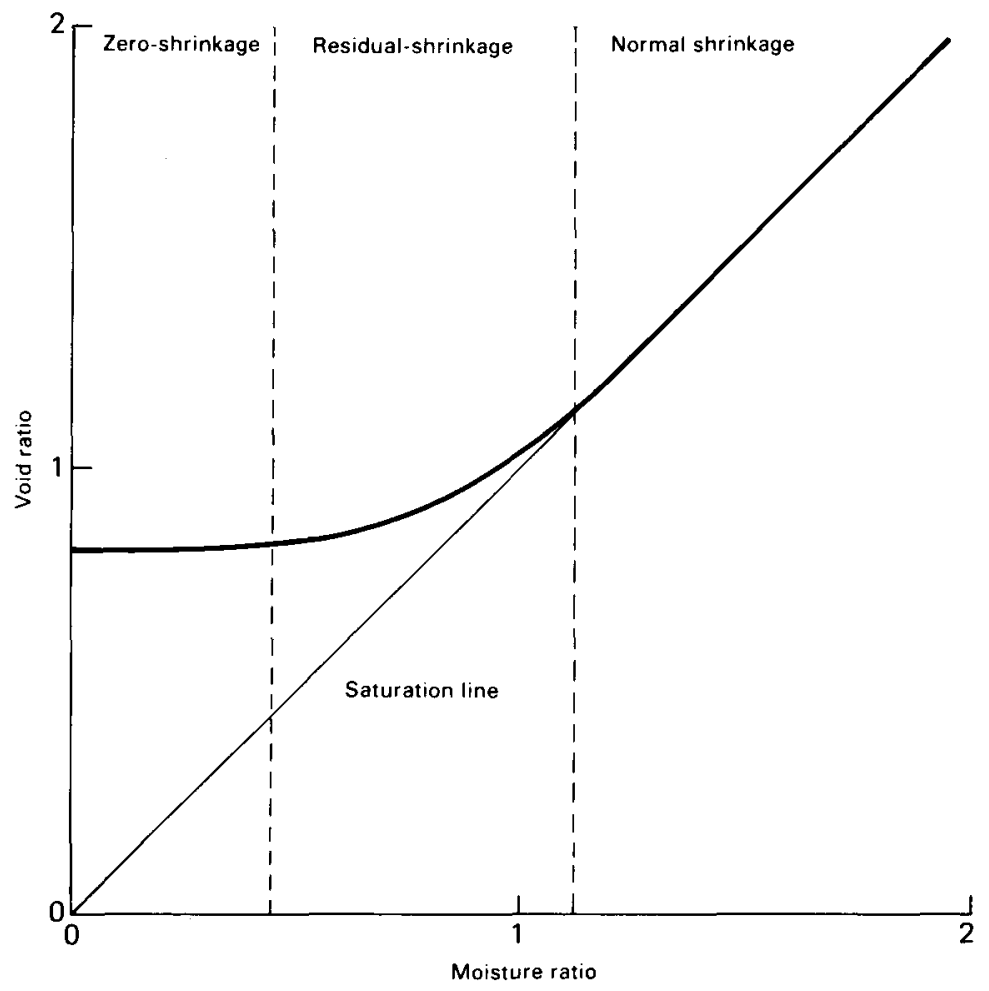

Fig. 3. General form of the shrinkage characteristic with three shrinkage phases; void ratio $=$ volume of pores/volume of solids; moisture ratio $=$ volume of water/volume of solids.

converted into change of volume of soil aggregates:

$$
\frac{V_{2}}{V_{1}}=\frac{1+e_{2}}{1+e_{1}}
$$

in which:

$V_{1}, e_{1}=$ volume and void ratio, respectively, of soil aggregates at moisture content 1

$V_{2}, e_{2}=$ volume and ratio, respectively, of soil aggregates at moisture content 2

On a macroscopic level, volume changes of soil aggregates result in the occurence of shrinkage cracks and surface subsidence. This has important consequences for both agricultural and non-agricultural users of a soil. In some cases, these consequences are mainly unwanted. An example is the transport of water and solutes via shrinkage cracks to the subsoil, bypassing the root zone. This may result in inefficient sprinkler irrigation and water and nutrient shortage of plants, but also in rapid 
pollution of groundwater (Thomas \& Phillips, 1979; Coles \& Trudgill, 1985; Bronswijk, 1988). Other unwanted consequences of soil shrinkage are the destruction of buildings, pavements and pipelines in or on heavy clay soils (McCormack \& Wilding, 1975; Gillot, 1984). Jones \& Holtz (1973) estimated that the total damage in the USA resulting from swelling and shrinkage of soils amounted to $\$ 2255000000$ per year, more than twice the damage from floods, hurricanes, tornadoes and earthquakes.

In many cases, soil shrinkage has positive effects as well. Examples are the drainage of some heavy clay soils, where the hydraulic conductivity of the soil increases by cracking (Bouma et al, 1979). In arid regions, basin irrigation of vertisols is positively influenced by soil cracks promoting a deep infiltration of water (Swartz, 1966; Farbrother, 1972). Swelling and shrinkage is also a natural process to restore soil compaction. Finally, swelling and shrinkage improves soil structure (Wilding \& Hallmark, 1984; Bronswijk, 1989). The mentioned examples illustrate the large impact of swelling and shrinkage on behaviour of clay soils, both in a positive and a negative way.

Studies of Berndt \& Coughlan (1977) and Yule \& Ritchie (1980) have demonstrated that the behaviour of aggregates and small soil cores can be used to explain and predict field soil behaviour. Moreover, simulation models have been developed recently that calculate transient water transport in cracking clay soils (Bronswijk, 1988). In these models the shrinkage characteristic plays an important role, comparable with the water retention curve and the hydraulic conductivity curve. Because of this, knowledge about course and magnitude of shrinkage of soil aggregates becomes increasingly important.

In the Netherlands, large areas of clay soils occur (Fig. 4). Little is known about swelling and shrinkage processes in these soils. In this article the magnitude of potential swelling and shrinkage in Dutch clay soils is determined. Seven soils with various texture, location, parent material and land use were selected. In the laboratory the shrinkage characteristics of these soils were determined. Parameters like COLE (Coefficient Of Linear Extensibility) and PLE (Potential Linear Extensibility), which quantify the shrinkage of a soil upon drying, were measured as well. The consequences of the obtained results for field behaviour of clay soils in the Netherlands are discussed.

\section{Materials and methods}

\section{Soil properties}

Seven soils with various texture, location, parent material and land use were selected. These seven soil profiles are considered representative for the holocene clay soils that occur in the Netherlands. Their location is pictured in Figure 4. Of each soil horizon the following properties were determined:

- texture,

- $\mathrm{CaCO}_{3}$ and organic matter content,

- density of the solid phase, 


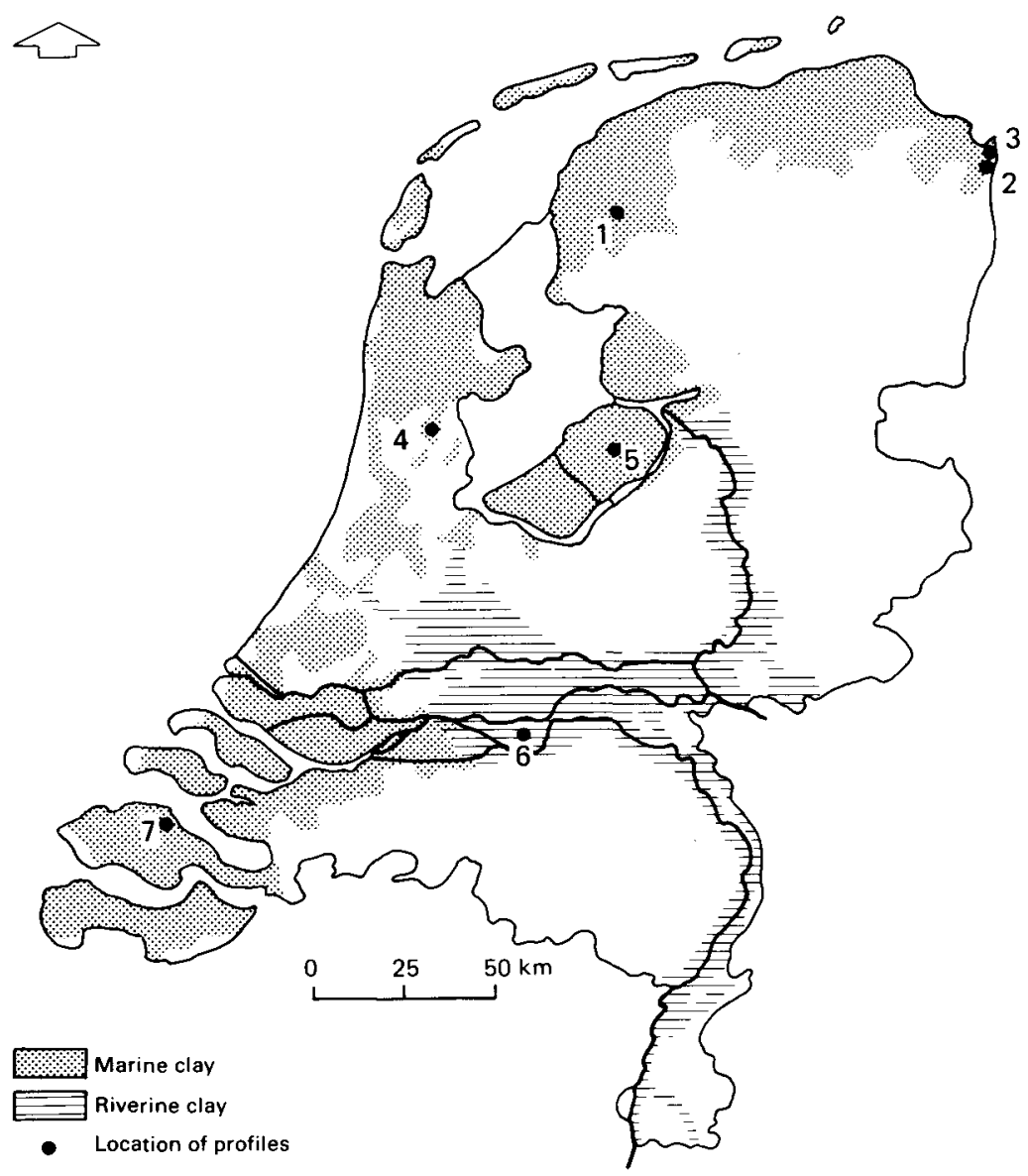

Fig. 4. Clay soil areas in the Netherlands. Locations of the seven profiles selected in this paper are marked. Numbers correspond with Tables 1 and 2.

- shrinkage characteristics,

- COLE and PLE values,

- water retention curve.

In the early spring of 1986 , on each site about ten natural clods of sizes ranging from 7 to $34 \mathrm{~cm}^{3}$ were taken from each soil horizon, in wet conditions. In the laboratory these clods were saturated for another two weeks. Three clods were used for determination of shrinkage characteristics and three clods were used for measurement of water retention curves. The remaining four clods were used to determine texture (by the Pipet method of Gee \& Bauder, 1986), organic matter content (by ignition loss at $500{ }^{\circ} \mathrm{C}$ ), $\mathrm{CaCO}_{3}$ content (with Scheibler apparatus), and density of the solid phase (by the Pycnometer method of Blake \& Hartge, 1986). The clay minerals of the seven selected profiles consist mainly of illite (30-40 \%) and smectite 
(20-40 \%) (Breeuwsma, pers. comm.). Water retention curves were determined on a sand box and with pressure membrane apparatus. The characterization of the seven soil profiles is given in Table 1 .

Table 1. Brief description and composition of seven selected clay soils in the Netherlands of which the shrinkage behaviour was determined. Numbers before location names correspond with Fig. 2 . $\varrho_{s}=$ density of the solid phase.

\begin{tabular}{|c|c|c|c|c|c|c|c|c|c|}
\hline \multirow[t]{3}{*}{ Location } & \multirow{3}{*}{$\begin{array}{l}\text { Depth } \\
\text { (cm) }\end{array}$} & \multirow[t]{3}{*}{ Horizon } & \multirow{3}{*}{$\begin{array}{l}\varrho_{s} \\
\left(\mathrm{~g} / \mathrm{cm}^{3}\right)\end{array}$} & \multicolumn{6}{|c|}{ Composition } \\
\hline & & & & \multicolumn{2}{|c|}{$\begin{array}{l}\text { in weight } \% \\
\text { of the soil }\end{array}$} & \multicolumn{4}{|c|}{$\begin{array}{l}\text { in weight } \% \\
\text { of mineral parts }\end{array}$} \\
\hline & & & & $\mathrm{CaCO}_{3}$ & $\begin{array}{l}\text { organic } \\
\text { matter }\end{array}$ & $<2$ & $2-16$ & $16-50$ & $>50 \mu \mathrm{m}$ \\
\hline \multirow[t]{4}{*}{ 1. Oosterend } & $0-22$ & A11 & 2.52 & 0.0 & 10.3 & 39.9 & 20.9 & 33.4 & 5.8 \\
\hline & $22-42$ & $\mathrm{ACg}$ & 2.60 & 0.0 & 6.9 & 40.7 & 25.9 & 28.3 & 5.1 \\
\hline & $42-78$ & Clg & 2.66 & 2.5 & 4.5 & 58.1 & 24.7 & 16.2 & 1.1 \\
\hline & $78-120$ & $\mathrm{C} 2 \mathrm{~g}$ & 2.68 & 6.9 & 2.2 & 24.1 & 14.3 & 53.5 & 8.1 \\
\hline \multirow[t]{5}{*}{ 2. Nieuw Beerta } & $0-26$ & $A p$ & 2.64 & 1.4 & 4.8 & 45.4 & 27.8 & 16.6 & 10.2 \\
\hline & 26- 34 & A12 & 2.61 & 0.8 & 3.9 & 45.9 & 27.4 & 18.9 & 6.8 \\
\hline & 34- 56 & Cl1g & 2.62 & 1.7 & 2.2 & 51.6 & 29.2 & 15.4 & 3.8 \\
\hline & $56-75$ & $\mathrm{C} 12 \mathrm{~g}$ & 2.68 & 3.3 & 1.9 & 39.1 & 24.1 & 32.8 & 4.0 \\
\hline & $75-107$ & $\mathrm{C} 13 \mathrm{~g}$ & 2.69 & 0.3 & 3.0 & 59.3 & 31.7 & 6.9 & 2.1 \\
\hline \multirow[t]{5}{*}{ 3. $\mathrm{N}$} & j1 $0-29$ & Ap & 2.65 & 9.0 & 3.3 & 52.0 & 24.2 & 20.4 & 3.4 \\
\hline & 29- 40 & $\mathrm{AC}$ & 2.67 & 10.6 & 2.9 & 62.9 & 17.0 & 17.7 & 2.4 \\
\hline & $40-63$ & $\mathrm{C} 21$ & 2.69 & 11.3 & 2.7 & 52.4 & 25.3 & 18.3 & 4.0 \\
\hline & $63-80$ & $\mathrm{C} 22 \mathrm{~g}$ & 2.66 & 9.8 & 2.8 & 55.8 & 24.1 & 16.7 & 3.4 \\
\hline & $80-100$ & $\mathrm{C} 23 \mathrm{~g}$ & 2.69 & 11.6 & 2.2 & 59.6 & 26.4 & 12.2 & 1.8 \\
\hline \multirow[t]{4}{*}{ 4. Schermerhorn } & $0-21$ & A11 & 2.59 & 11.7 & 5.9 & 34.8 & 17.9 & 27.9 & 19.5 \\
\hline & $21-52$ & A12 & 2.61 & 11.1 & 6.2 & 42.9 & 22.1 & 26.5 & 8.5 \\
\hline & $52-77$ & $\mathrm{C} 21 \mathrm{~g}$ & 2.62 & 17.6 & 3.7 & 32.1 & 20.4 & 33.2 & 14.2 \\
\hline & $77-100$ & $\mathrm{C} 22 \mathrm{~g}$ & 2.63 & 18.8 & 3.1 & 16.2 & 10.1 & 37.8 & 36.0 \\
\hline \multirow[t]{5}{*}{ 5. Dronten } & $0-22$ & Ap1 & 2.66 & 9.9 & 2.6 & 36.8 & 22.2 & 27.5 & 13.5 \\
\hline & 22- 38 & A12 & 2.66 & 8.1 & 2.2 & 45.6 & 27.2 & 22.9 & 4.3 \\
\hline & $38-60$ & $\mathrm{C} 22 \mathrm{~g}$ & 2.63 & 6.6 & 7.6 & 35.3 & 43.9 & 19.7 & 1.1 \\
\hline & $60-90$ & $\mathrm{C} 23 \mathrm{~g}$ & 2.59 & 5.8 & 7.0 & 15.9 & 23.9 & 58.2 & 2.0 \\
\hline & $90-110$ & $\mathrm{C} 24 \mathrm{~g}$ & 2.57 & 4.6 & 10.5 & 20.2 & 27.2 & 51.2 & 1.4 \\
\hline \multirow[t]{4}{*}{ 6. Bruchem } & $0-18$ & A11 & 2.52 & 0.0 & 9.9 & 58.1 & 30.7 & 10.2 & 1.0 \\
\hline & $18-30$ & A12 & 2.60 & 0.0 & 7.5 & 55.8 & 35.5 & 8.1 & 0.6 \\
\hline & $30-58$ & Cllg & 2.64 & 0.0 & 3.7 & 59.6 & 29.5 & 10.1 & 0.8 \\
\hline & $58-85$ & $\mathrm{Cl} 2 \mathrm{~g}$ & 2.59 & 0.0 & 3.8 & 51.7 & 37.0 & 9.6 & 1.7 \\
\hline \multirow[t]{4}{*}{ 7. Kats } & $0-35$ & Ap & 2.67 & 10.2 & 2.1 & 30.8 & 15.7 & 30.2 & 23.3 \\
\hline & $35-60$ & $\mathrm{C} 21 \mathrm{~g}$ & 2.67 & 13.6 & 1.6 & 46.4 & 20.5 & 21.2 & 11.9 \\
\hline & $60-80$ & $\mathrm{C} 22 \mathrm{~g}$ & 2.70 & 15.7 & 1.3 & 41.9 & 18.3 & 23.3 & 15.5 \\
\hline & $80-95$ & $\mathrm{C} 23 \mathrm{~g}$ & 2.69 & 9.5 & 0.3 & 16.2 & 6.7 & 21.0 & 56.1 \\
\hline
\end{tabular}




\section{Shrinkage characteristics}

In order to determine shrinkage characteristics, each clod was briefly immersed in SARAN-F310 resin (resin to solvent ratio $1: 5, \mathrm{w} / \mathrm{w}$ ) and allowed to dry in the laboratory. The applied SARAN-coating is very elastic, impermeable to water and permeable to water vapour (Brasher et al., 1966). As the clods dry and shrink, the elastic coating remains tightly fitted around the clods. By repeated weighing and under water weighing, both weight and volume of the clod can be determined at different stages of shrinkage, in a non-destructive way. After two to four weeks, weight losses became negligible. The SARAN-coated clods were oven-dried in order to measure final dry volume and dry weight.

\section{Cole and PLE}

The Coefficient Of Linear Extensibility (COLE) (Grossman et al., 1968) is a parameter that quantifies the swelling and shrinkage potential of a soil layer. COLE is defined as:

$$
\text { COLE }=\left(\frac{V_{\text {wet }}}{V_{\text {dry }}}\right)^{1 / 3}-1
$$

in which:

$V_{\text {wet }}, V_{\text {dry }}=$ volume of a soil aggregate in wet and dry state, respectively.

To quantify potential swelling and shrinkage of a soil in situ, the swelling and shrinkage potential of the different layers of that soil should be taken into account. With respect to this, the Potential Linear Extensibility (PLE) was defined:

$$
\operatorname{PLE}=\operatorname{COLE}(1) \times z(1)+\operatorname{COLE}(2) \times z(2)+\ldots+\operatorname{COLE}(n) \times z(n)(\mathrm{cm})(8)
$$

in which:

$\operatorname{COLE}(n)=\operatorname{COLE}$ value of $n$th soil horizon $(-)$

$z(n)=$ thickness of $n$th soil horizon $(\mathrm{cm})$

$z(1)+z(2)+\ldots+z(n)=100 \mathrm{~cm}$

For a given soil, values of COLE and PLE depend on definition of $V_{\text {wet }}$ and $V_{\text {dry }}$. In the USA soil classification system (Soil Survey Staff, 1975), $V_{\text {wet }}$ is defined as the volume of a soil aggregate at a pressure head of $-333 \mathrm{~cm}$. $V_{\text {dry }}$ is the volume of an aggregate at air-dryness. In practice, air-dry sometimes is replaced by ovendry. To quantify potential swelling and shrinkage in Dutch clay soils, this definition is not very suitable. In Dutch climatic circumstances, soils are often much wetter than moisture contents corresponding with a pressure head of $-333 \mathrm{~cm}$. At the same time they will never become as dry as 'air-dry' (except for a very thin surface layer). Because of this, a COLE calculated between $h=-333 \mathrm{~cm}$ and air-dry does not give any information on the magnitude of swelling and shrinkage to be expected in Dutch field situations. Therefore in this article we first have calculated COLE and 
PLE with $V_{\text {wel }}$, volume of an aggregate at saturation, and $V_{\mathrm{dry}}$, volume of an aggregate at a pressure head of $-16000 \mathrm{~cm}$. It should be kept in mind that, independant of the definition of $V_{\text {wet }}$ and $V_{\text {dry }}$, both COLE and PLE are indicating potential swelling and shrinkage. If measured between saturation and $h=-16000 \mathrm{~cm}$, COLE and PLE are upper limits for field shrinkage in the Netherlands, which will normally not be reached in the field in subsoils, except in special cases, like removal of the topsoil or planting of a deep-rooting crop. Actual swelling and shrinkage are determined not only by soil properties but also by the hydrology of the soil in situ. It can for instance easily happen in the field that a well-drained soil with low COLE and PLE exhibits far more cracking and subsidence than a poorly drained soil with high COLE and PLE.

For the sake of international comparison, COLE and PLE values have also been calculated over the range $h=-333 \mathrm{~cm}$ to oven-dry.

\section{Results and discussion}

\section{Shrinkage characteristics}

The measured shrinkage characteristics are presented in Figure 5. The shapes of the shrinkage characteristics, with respect to magnitude of shrinkage, relation with pressure head values, air entry points, start and end of shrinkage phases etc. vary strongly from one soil to another. Only few curves, for instance Schermerhorn A12, resemble the theoretical picture, including a substantial normal shrinkage phase, of Figure 3. This can be ascribed to either the presence of small amounts of silt and sand particles which may locally restrict shrinkage and induce air entry, or to the development of micro-cracks inside of the soil clods during drying. Because in all cases the shape of the measured shrinkage characteristics was reproducable using clods of various size, the first explanation is the most likely.

Most of the selected soil horizons show large shrinkage, as is clearly visible from the large decrease of void ratio of the drying aggregates. In all aggregates, shrinkage starts immediately at the first water extraction at saturation. Moreover, shrinkage expressed as $\mathrm{d} e / \mathrm{d} \vartheta$ is largest near saturation, and becomes smaller when the soil gets dryer. Because of the influence of clay content, clay mineralogy, cation exchange capacity and organic matter on the shrinkage process, there are also many differences in behaviour of the various soils. In some soil layers, like Schermerhorn C22g, shrinkage stops at pressure heads of minus a few hundred $\mathrm{cm}$ 's. In other soils, shrinkage continues far below pressure heads of $-16000 \mathrm{~cm}$, e.g. the subsoils of Nieuw Beerta and Bruchem and the whole Kats profile. Not only the magnitude but also the course of the shrinkage process differs from one soil horizon to another. In some horizons, the change from normal to residual shrinkage (the air-entry point) lies very close to saturation, as is the case in the complete Nieuw Statenzijl profile. In other soils, this point lies somewhere between a pressure head of $-10 \mathrm{~cm}$ and $-16000 \mathrm{~cm}$. An extreme case is the Bruchem $\mathrm{Cl} 1 \mathrm{~g}$ horizon, where normal shrinkage continues until pressure heads much lower than $-16000 \mathrm{~cm}$.

Another special case is the Dronten subsoil. This subsoil is only half ripe, which 


\section{J. J. B. BRONSWIJK AND J. J. EVERS-VERMEER}

\section{Profile 1. Oosterend}

Hor 1zon all (0-22 cel
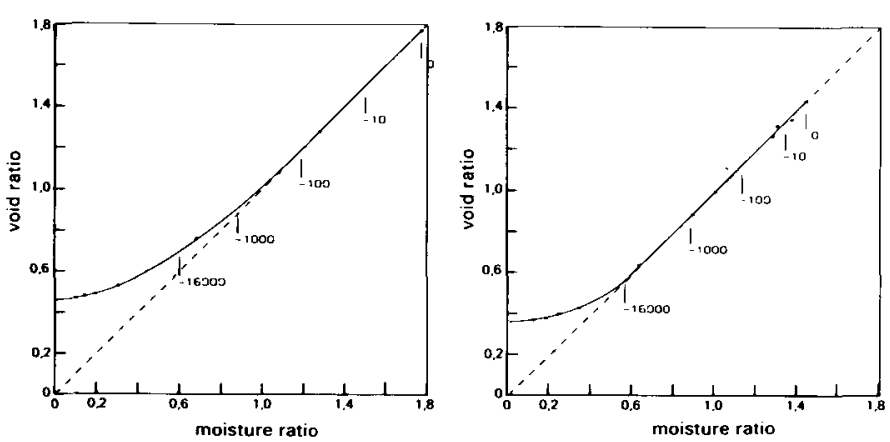

Profile 2. Nieuw-Beerta

Horizon C2g $(78-120 \mathrm{~cm})$
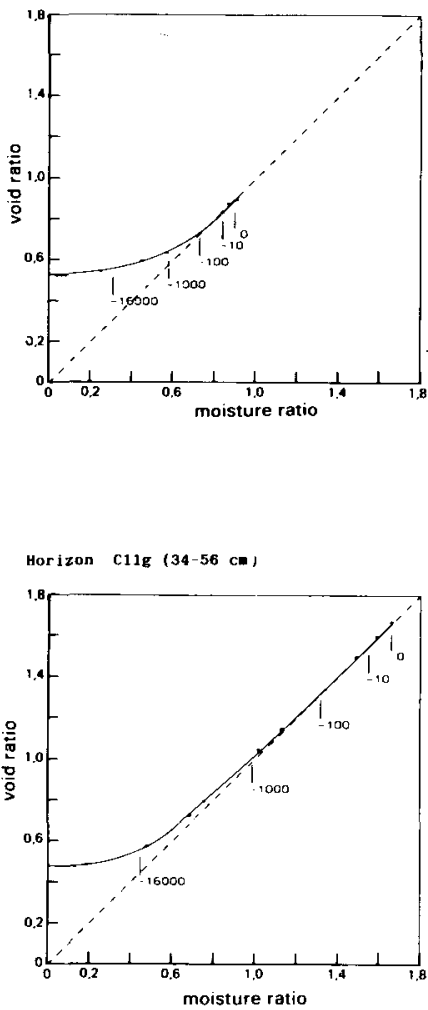

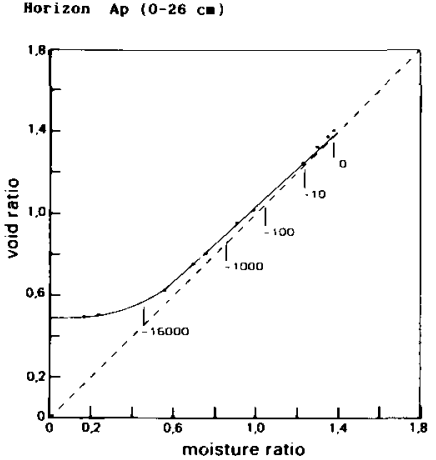

Horizon $\mathrm{Cl} 2 \mathrm{~g}(56-75 \mathrm{~cm})$

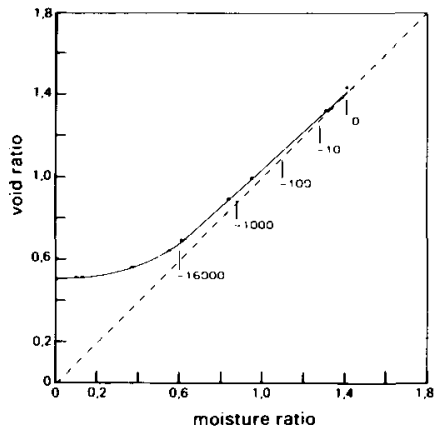

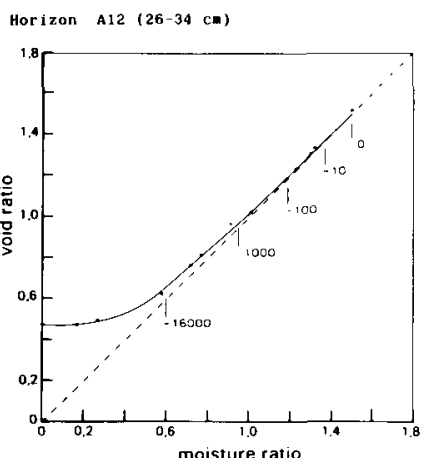

Horizon C13g $(75-107 \mathrm{~cm})$

Horizon cig $(42-78 \mathrm{~cm})$
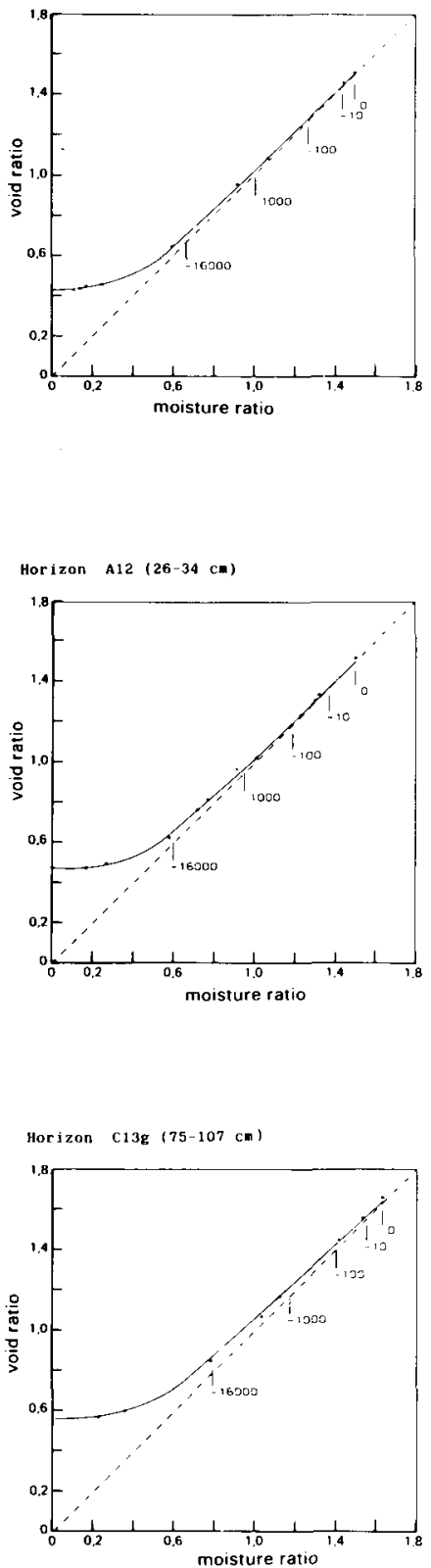

Fig. 5. Shrinkage characteristics of natural aggregates of seven clay soil profiles from the Netherlands; void ratio $=$ volume of pores $/$ volume of solids; moisture ratio = volume of water/volume of solids. Some values of pressure heads $(\mathrm{cm})$ are also indicated. 
Profile 3. Nieuw Statenziil

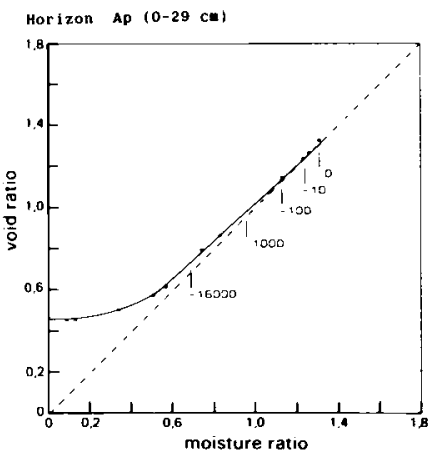

Horizor C22g $(63-80 \mathrm{~cm})$

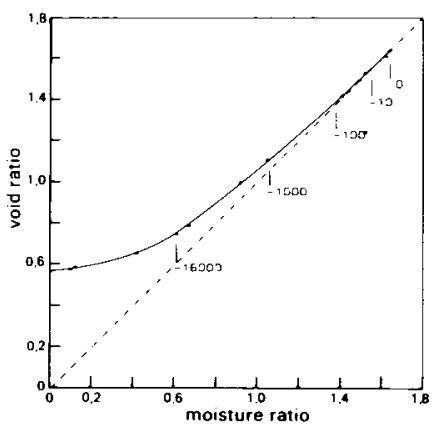

Horizon A12 (21-52 CM)

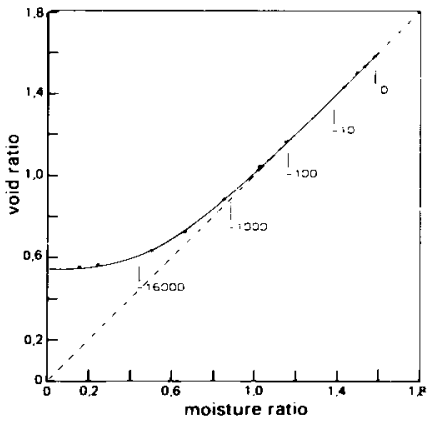

Horizon AC (29-40 cos)

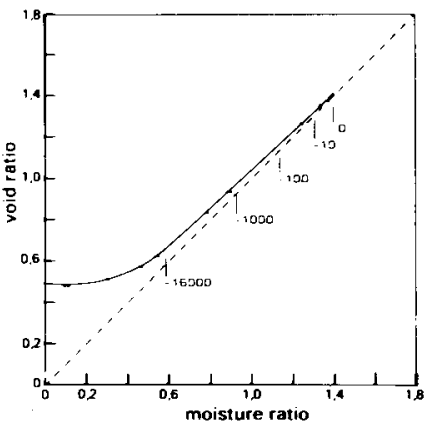

Horizon C23g (80-100 ca)

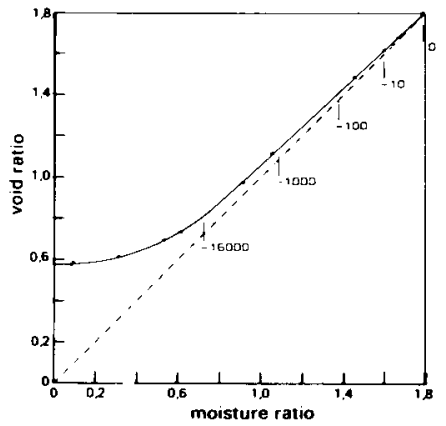

Horizon C2) $\{52-77 \mathrm{~cm}\}$

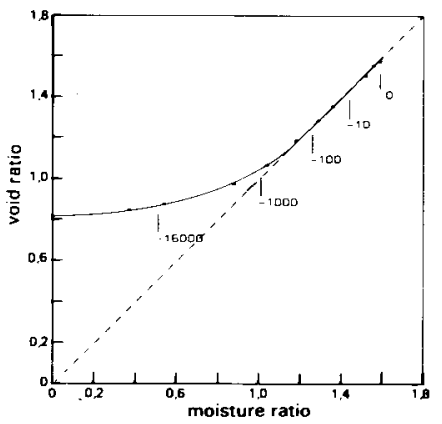

Horizon C21 (40-63 ca)

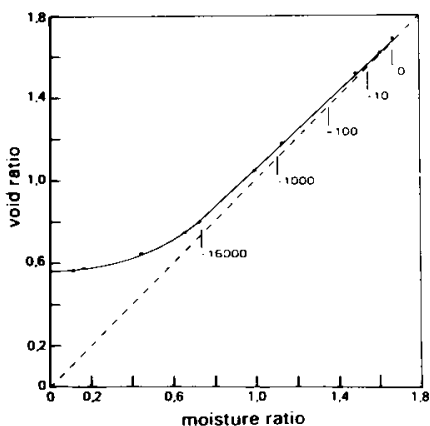

Profile 4. Schermershorn

Horizon All $(0-21 \mathrm{~cm})$

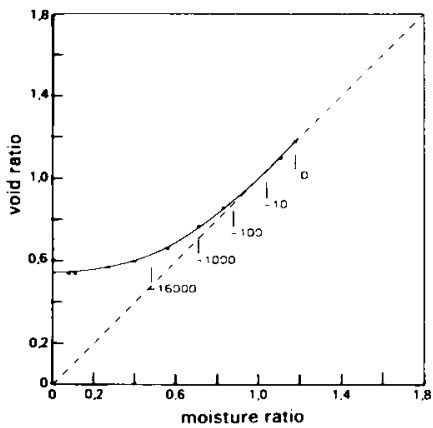

Horizon C22g $(77-100 \mathrm{~cm})$

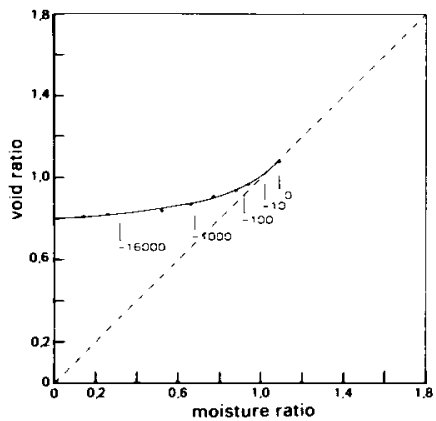

Fig. 5. Continued 


\section{J. J. B. BRONSWIJK AND J. J. EVERS-VERMEER}

\section{Profile 5. Dronten}
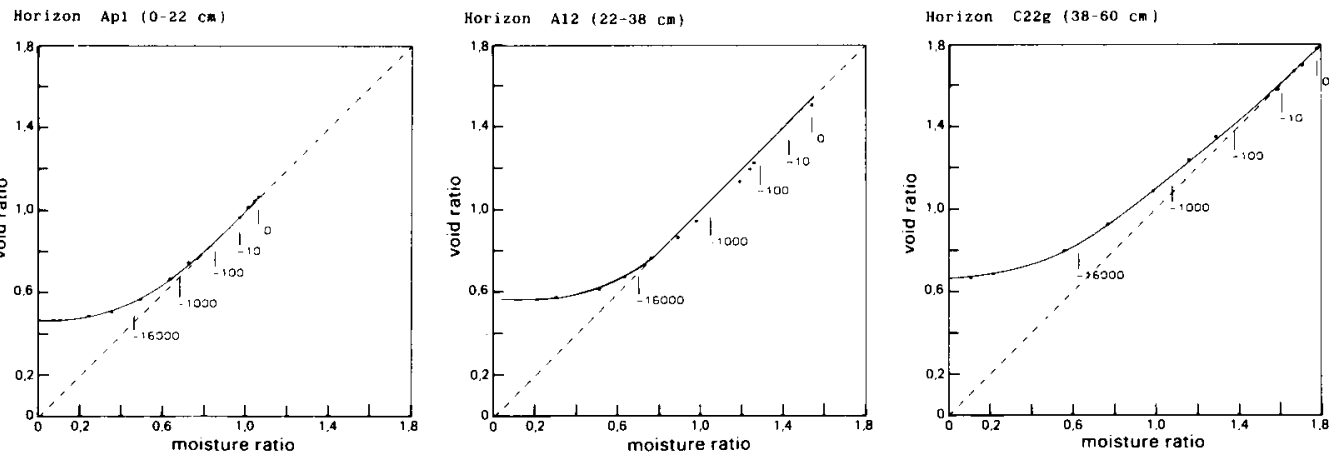

\section{Profile 6. Bruchem}

Horizon C24g $(90-110 \mathrm{~cm})$

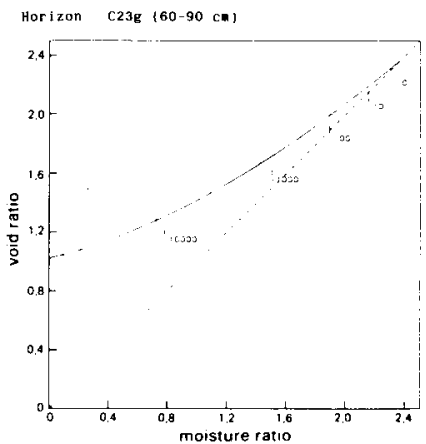

Horizon A12 (18-30 cm)

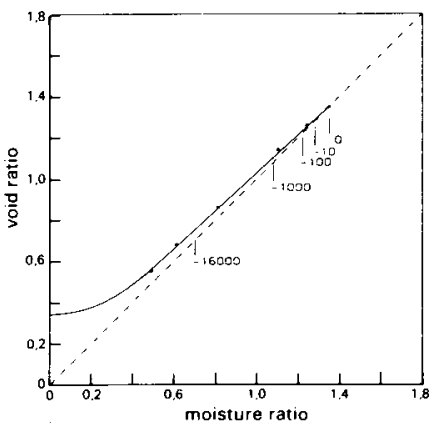

Horizon cl1g $(30-58 \mathrm{~cm})$

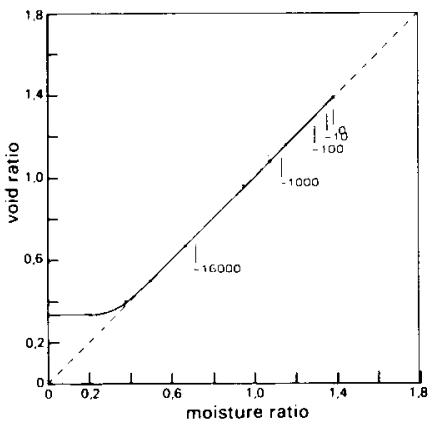

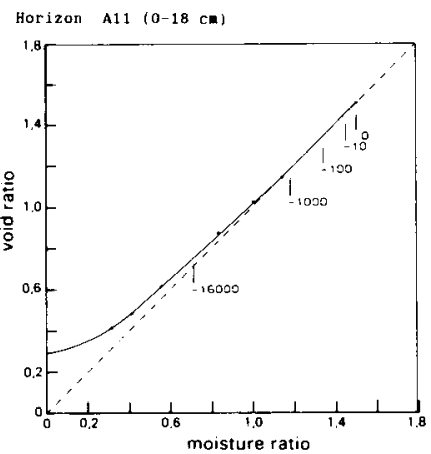

Horizon $\mathrm{C} 12 \mathrm{~g}(58-85 \mathrm{Cl})$

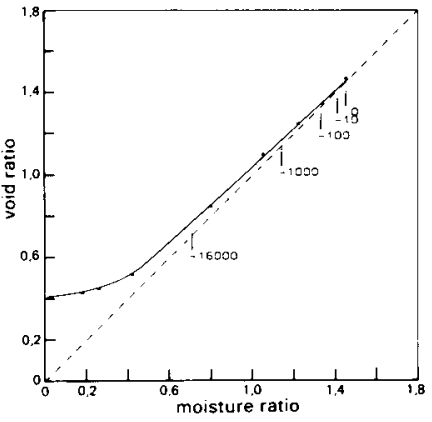

Fig. 5. Continued 

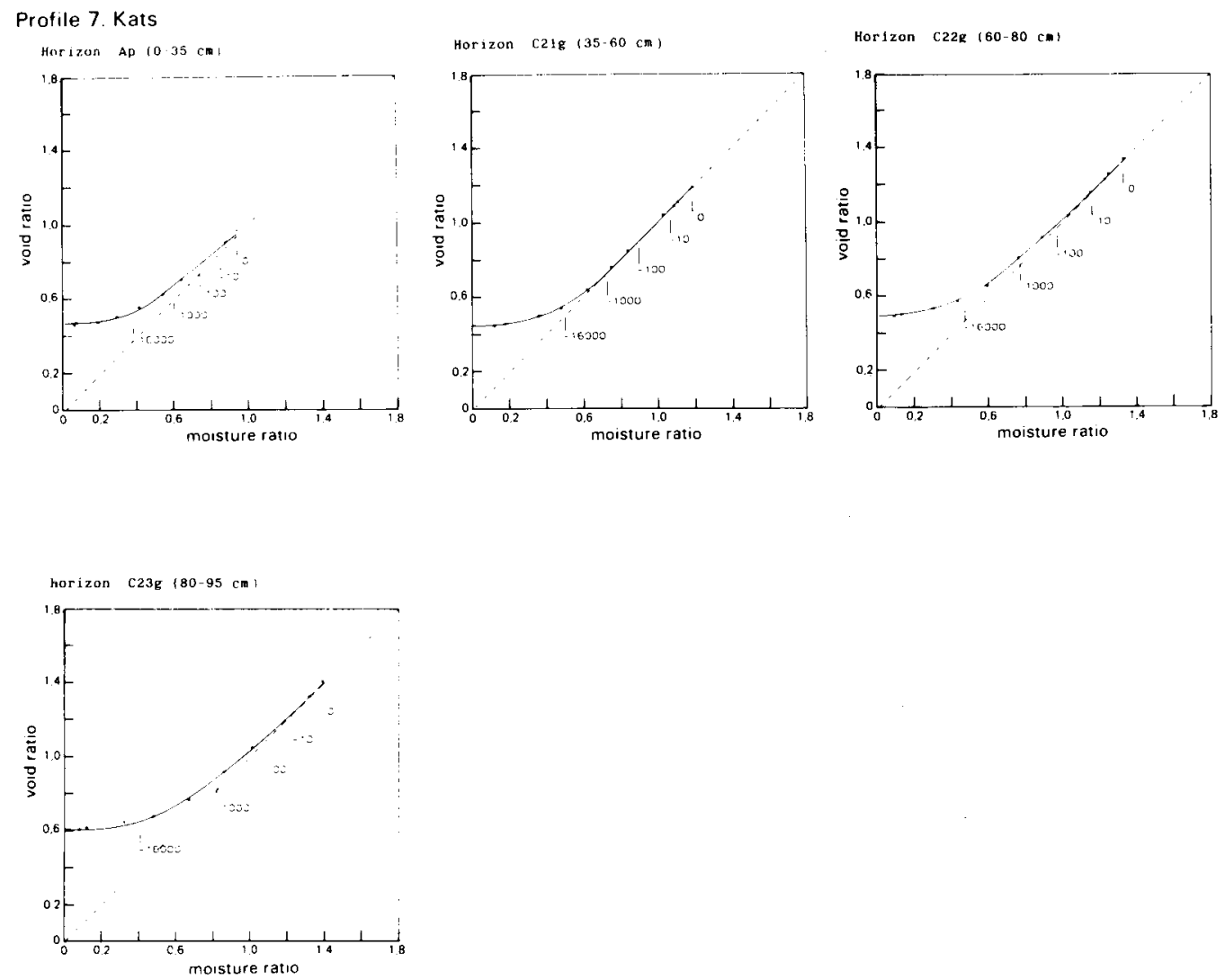

Fig. 5. Continued

results in a markedly different shape of the shrinkage characteristic. In this subsoil, total shrinkage is high, but air entry occurs much earlier and is much larger than in most of the other soils. It can be expected that, after a few wetting-drying cycles, total shrinkage will become smaller and the shrinkage curve will approach the saturation line, as a result of ripening. It is likely that some ripening also plays a role in the observed shrinkage of some fluvial soils. Miedema (1987) reported that aggregates of a holocene fluvial soil did not regain their original volume after extreme drying and rewetting. This effect will be most pronounced in poorly drained subsoils.

The observed course and magnitude of shrinkage upon drying has important consequences for the field behaviour of clay soils in the Netherlands. Some clay soils show normal shrinkage from saturation till a pressure head much lower than $-16000 \mathrm{~cm}$ 's. An extreme example of this is the Bruchem $\mathrm{C} 11 \mathrm{~g}$ horizon (Profile 6). This means that under Dutch climatic circumstances, the aggregates in this soil 
horizon always remain fully saturated. Air is only present in inter-aggregate pores like shrinkage cracks. Naturally, this strongly affects the air availability and root development in this type of soil. Soil structure becomes very important because to optimize root development, the distance between air-containing macropores should be minimized. Furthermore, phenomena like partial anaerobiosis (Leffelaar, 1987) are likely to occur in this type of heavy clay soils.

\section{COLE and PLE}

The values of volume decrease, COLE and PLE over three pressure head ranges are presented in Table 2. Volume decrease from saturation to oven-dry varies between $14 \%$ for the Schermerhorn C22g horizon and $49 \%$ for the Bruchem A11 horizon. Some horizons with relatively low clay contents of only 15-16\% show volume decreases of 15 to $20 \%$. Less than the heavy clay soils, but still considerable. Corresponding COLE values from saturation to oven-dry range from 0.052 to 0.248 . The PLE values over the same range for the seven profiles corresponds with the clay contents of the soils. The light clay soils of Kats and Schermerhorn have PLE values of about $13 \mathrm{~cm}$. The heavier clay soils of Nieuw Beerta and Nieuw Statenzijl have PLE values of about $17 \mathrm{~cm}$ and the soils traditional known as strong swelling and shrinking, indeed show the highest PLE values: $18.5 \mathrm{~cm}$ for Oosterend clay and 21.6 $\mathrm{cm}$ for Bruchem basin clay. The PLE value of $16.4 \mathrm{~cm}$ of the Dronten soil reflects partly the irreversible ripening proces upon oven-drying.

Volume changes between saturation and a pressure head of $-16000 \mathrm{~cm}$ are of more practical importance in the Netherlands. In this pressure head range, volume decreases vary from $13 \%$, again for the Schermerhorn subsoil, to $42 \%$ for the Nieuw Beerta C11g Horizon. Corresponding COLE values over this pressure head range are respectively 0.05 and 0.20 . The PLE values from 0 to $-16000 \mathrm{~cm}$ can be considered as the maximum surface subsidence that the considered soil can exhibit under Dutch climatic conditions. This maximum subsidence is about $11 \mathrm{~cm}$ for the light clay soils of Kats and Schermerhorn and also the heavy clay soil of Bruchem. The relatively low value of Bruchem is surprising but can be explained from the fact that in this soil shrinkage continues far below pressure heads of $-16000 \mathrm{~cm}$ and shrinkage in the range saturation to $-16000 \mathrm{~cm}$ is relatively small. The maximum subsidence of the soil surface is about $13 \mathrm{~cm}$ for the heavy clay soils of Oosterend, Nieuw Statenzijl and the partly unripe soil of Dronten. The heavy clay soil of Nieuw Beerta shows the largest maximum surface subsidence, namely $15 \mathrm{~cm}$. Whether these potential maximum subsidences are really reached in the field depends on hydrology and actual water loss of the soil in situ, but is not likely.

Because determination of COLE values requires much effort, and clay and organic matter contents of Dutch clay soils are already available or easily measured, it is worthwhile to try to predict COLE from these two soil properties. The best fit of COLE ( $-333 \mathrm{~cm}$ to oven-dry) against clay content (in weight $\%$ of the soil) is expressed by:

$$
\text { COLE }=0.002552 \text { clay content }+0.0118 r^{2}=0.59
$$


Table 2. Relative volume decrease $(\Delta v / v \times 100)$, coefficient of linear extensibility (COLE) for equal individual soil horizon and potential linear extensibility (PLE) for the entire soil profile of seven clay soils from the Netherlands. Values are presented for three different pressure head ranges.

\begin{tabular}{|c|c|c|c|c|c|c|c|c|c|c|}
\hline \multirow[t]{2}{*}{ Location } & \multirow[t]{2}{*}{ Horizon } & \multicolumn{3}{|c|}{$0 \mathrm{~cm}$ to $16000 \mathrm{~cm}$} & \multicolumn{3}{|c|}{$-333 \mathrm{~cm}$ to oven-dry } & \multicolumn{3}{|c|}{$0 \mathrm{~cm}$ to oven-dry } \\
\hline & & $\begin{array}{l}\Delta v / v \\
\times 100 \\
(\%)\end{array}$ & $\begin{array}{l}\text { COLE } \\
(-)\end{array}$ & $\begin{array}{l}\text { PLE } \\
\text { (cm) }\end{array}$ & $\begin{array}{l}\Delta v / v \\
\times 100 \\
(\%)\end{array}$ & $\begin{array}{l}\text { COLE } \\
(-)\end{array}$ & $\begin{array}{l}\text { PLE } \\
(\mathrm{cm})\end{array}$ & $\begin{array}{l}\Delta v / \nu \\
\times 100 \\
(\%)\end{array}$ & $\begin{array}{l}\text { COLE } \\
(-)\end{array}$ & $\begin{array}{l}\text { PLE } \\
(\mathrm{cm})\end{array}$ \\
\hline \multirow[t]{4}{*}{ 1. Oosterend } & A11 & 38.0 & 0.173 & & 26.9 & 0.110 & & 47.2 & 0.237 & \\
\hline & $\mathrm{ACg}$ & 34.9 & 0.154 & 13.1 & 32.5 & 0.140 & 11.2 & 44.0 & 0.213 & 18.5 \\
\hline & $\mathrm{Clg}$ & 31.4 & 0.134 & & 33.7 & 0.147 & & 42.9 & 0.205 & \\
\hline & $\mathrm{C} 2 \mathrm{~g}$ & 17.9 & 0.068 & & 9.3 & 0.030 & & 19.3 & 0.074 & \\
\hline \multirow[t]{5}{*}{ 2. Nieuw Beerta } & Ap & 34.9 & 0.154 & & 25.3 & 0.102 & & 38.0 & 0.173 & \\
\hline & $\mathrm{A} 12$ & 34.1 & 0.149 & & 29.0 & 0.121 & & 41.2 & 0.194 & \\
\hline & $\mathrm{C} 11 \mathrm{~g}$ & 42.0 & 0.199 & 15.3 & 30.9 & 0.131 & 11.9 & 44.6 & 0.218 & 16.9 \\
\hline & $\mathrm{C} 12 \mathrm{~g}$ & 31.1 & 0.132 & & 25.3 & 0.102 & & 38.7 & 0.177 & \\
\hline & $\mathrm{C} 13 \mathrm{~g}$ & 30.5 & 0.129 & & 32.1 & 0.138 & & 41.4 & 0.195 & \\
\hline \multirow{5}{*}{$\begin{array}{l}\text { 3. Nieuw } \\
\text { Statenzijl }\end{array}$} & $\mathrm{Ap}$ & 25.5 & 0.103 & & 29.2 & 0.122 & & 37.2 & 0.168 & \\
\hline & $\mathrm{AC}$ & 31.1 & 0.132 & & 27.9 & 0.115 & & 37.9 & 0.172 & \\
\hline & $\mathrm{C} 21$ & 32.0 & 0.137 & 13.3 & 30.9 & 0.131 & 12.6 & 41.8 & 0.198 & 17.0 \\
\hline & $\mathrm{C} 22 \mathrm{~g}$ & 34.1 & 0.149 & & 30.3 & 0.128 & & 40.4 & 0.188 & \\
\hline & $\mathrm{C} 23 \mathrm{~g}$ & 35.4 & 0.157 & & 30.3 & 0.128 & & 43.6 & 0.210 & \\
\hline \multirow[t]{4}{*}{ 4. Schermerhorn } & All & 25.1 & 0.101 & & 15.6 & 0.058 & & 28.8 & 0.120 & \\
\hline & A 12 & 38.0 & 0.173 & 11.3 & 25.3 & 0.102 & 6.3 & 40.5 & 0.189 & 13.2 \\
\hline & $\mathrm{C} 21 \mathrm{~g}$ & 27.0 & 0.111 & & 15.1 & 0.056 & & 29.6 & 0.124 & \\
\hline & $\mathrm{C} 22 \mathrm{~g}$ & 13.1 & 0.048 & & 6.6 & 0.023 & & 14.1 & 0.052 & \\
\hline \multirow[t]{5}{*}{ 5. Dronten } & Apl & 25.5 & 0.103 & & 17.4 & 0.066 & & 29.2 & 0.122 & \\
\hline & $\mathrm{A} 12$ & 31.1 & 0.132 & & 27.1 & 0.111 & & 37.7 & 0.171 & \\
\hline & $\mathrm{C} 22 \mathrm{~g}$ & 34.6 & 0.152 & 12.7 & 27.3 & 0.112 & 10.0 & 39.9 & 0.185 & 16.4 \\
\hline & $\mathrm{C} 23 \mathrm{~g}$ & 32.0 & 0.137 & & 28.6 & 0.119 & & 40.2 & 0.187 & \\
\hline & $\mathrm{C} 24 \mathrm{~g}$ & 21.5 & 0.084 & & 20.4 & 0.079 & & 30.1 & 0.127 & \\
\hline \multirow[t]{4}{*}{ 6. Bruchem } & All & 30.5 & 0.129 & & 42.8 & 0.205 & & 48.6 & 0.248 & \\
\hline & A 12 & 25.3 & 0.102 & 11.6 & 38.5 & 0.176 & 18.2 & 43.4 & 0.209 & 21.6 \\
\hline & Cllg & 28.1 & 0.116 & & 40.4 & 0.188 & & 44.1 & 0.214 & \\
\hline & $\mathrm{C} 12 \mathrm{~g}$ & 28.1 & 0.116 & & 37.6 & 0.170 & & 42.8 & 0.205 & \\
\hline \multirow[t]{4}{*}{ 7. Kats } & Ap & 21.9 & 0.086 & & 13.9 & 0.051 & & 25.3 & 0.102 & \\
\hline & $\mathrm{C} 2 \mathrm{lg}$ & 29.0 & 0.121 & 11.4 & 20.0 & 0.077 & 6.7 & 33.9 & 0.148 & 13.3 \\
\hline & $\mathrm{C} 22 \mathrm{~g}$ & 32.0 & 0.137 & & 21.1 & 0.082 & & 35.9 & 0.160 & \\
\hline & $\mathrm{C} 23 \mathrm{~g}$ & 31.1 & 0.132 & & 18.4 & 0.070 & & 32.9 & 0.142 & \\
\hline
\end{tabular}

When the organic matter content (in weight $\%$ of the soil) is taken into the regression analysis, we get the following result:

$$
\begin{aligned}
\text { COLE }= & 0.002636 \text { clay content }+0.006 \text { organic matter content }-0.171 \\
& r^{2}=0.71
\end{aligned}
$$




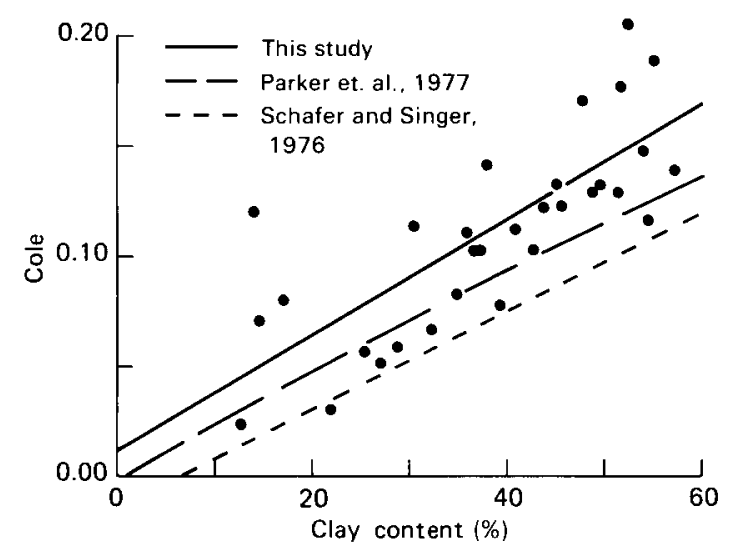

Fig. 6. Relation between clay content (weight percentage) and coefficient of linear extensibility (COLE) over the range $h=-333 \mathrm{~cm}$ to oven-dry for aggregates of seven clay soil profiles from the Netherlands. The best fit is expressed by COLE $=0.002552 \times$ clay content +0.0118 with $r^{2}$ equal to 0.59 . Relations between COLE and clay content of Parker et al. (1977), and Schafer \& Singer (1976) are also presented.

Relations between total clay content and COLE of Schafer \& Singer (1976), and Parker et al. (1977) for various clay soils from the USA, were compared with the results of the present study (Fig. 6). Over the whole range, COLE values of Dutch clay soils are somewhat higher, which is probably due to the presence of substantial amounts of organic matter.

\section{Classification of shrinkage of Dutch clay soils}

In order to evaluate whether the measured shrinkage in Dutch clay soils is small or large, we compared the presented results with data from other studies. A summary of studies from several countries in which COLE values (between oven-dry and $h$ $=-333 \mathrm{~cm}$ ) of clay soils have been determined is presented in Table 3 . The majority of Dutch clay soils have COLE values between 0.11 and 0.15 ( see Table 2). Compared with foreign soils, these values are neither very high nor very low. An exception is the Bruchem basin clay with a COLE value of 0.205 which belongs to the highest COLE values of the world. Due to the Dutch climate, however, actual field shrinkage will always be much smaller than for instance in arid Vertisols.

When we compare the presented measurements with an often used classification of swelling and shrinkage potential of a soil based on COLE values (Parker et al., 1977) we find that the heavy clay soils from Oosterend, Nieuw Beerta, Nieuw Statenzijl and Bruchem belong to the class of soils with very high shrink-swell potential. The soils from Schermerhorn and Kats show medium to high shrink-swell potential in the different horizons (Table 4).

Reeve et al. (1980) presented a classification of shrinkage for British soils based upon PLE values. In this classification the soil as a whole is considered and not the 
Table 3. Comparison of measured minimum and maximum COLE-values ( $h=-333 \mathrm{~cm}$ to oven-dry) of Dutch clay soils with values of foreign clay soils.

\begin{tabular}{llll}
\hline Location & $\begin{array}{l}\text { Number of } \\
\text { samples }\end{array}$ & COLE range & Source \\
USA & 30 & $0.004-0.181$ & Franzmeier \& Ross (1968) \\
Yolo County, USA & 16 & $0.001-0.118$ & Schafer \& Singer (1976) \\
Ontario, USA & 13 & $0-0.088$ & Ross (1978) \\
Tanzania & 6 & $0.037-0.230$ & Ross (1978) \\
Great Britain & 20 & $0.049-0.232$ & Reeve et al. (1980) \\
Israel & 67 & 0.0 .277 & Smith et al. (1985) \\
Saskatchewan, Canada & 33 & $0.021-0.168$ & Dasog et al. (1988) \\
& & $0.023-0.205$ & This study \\
\hline
\end{tabular}

Table 4. Rating of shrink-swell potential of soil horizons based upon COLE values (Parker et al., 1977).

\begin{tabular}{lll}
\hline $\begin{array}{l}\text { Shrink-swell } \\
\text { potential }\end{array}$ & $\begin{array}{l}\text { COLE } \\
(-333 \mathrm{~cm} \text { to air-dry }) \\
\text { Low }\end{array}$ & Horizons \\
Medium & 0.03 & $\begin{array}{l}\text { Oosterend C2g } \\
\text { Schermerhorn C22g }\end{array}$ \\
High & $0.03-0.06$ & $\begin{array}{l}\text { Schermerhorn A11, C21g } \\
\text { Kats Ap }\end{array}$ \\
& $0.06-0.09$ & $\begin{array}{l}\text { Dronten Ap1, C24g } \\
\text { Kats C21g, C22g, C23g }\end{array}$ \\
Very high & $>0.09$ & $\begin{array}{l}\text { Nieuw Beerta } \\
\text { Nieuw Statenzijl } \\
\text { Bruchem } \\
\text { Oosterend A11, ACg, C1g } \\
\text { Schermerhorn A12 } \\
\text { Dronten A12, C22g, C23g }\end{array}$ \\
& &
\end{tabular}

different horizons separately. Reeve et al. distinguished three shrinkage categories:

- PLE >14: large shrinkage,

$-9 \leq \mathrm{PLE} \leq 14$ : moderate shrinkage,

- PLE <9: low shrinkage.

In the quoted paper, PLE was calculated between a pressure head of $-333 \mathrm{~cm}$ and oven-dryness. As is explained above, in the Netherlands a definition of PLE between $0 \mathrm{~cm}$ and $-16000 \mathrm{~cm}$ is of more practical use. Therefore it is proposed to classify shrinkage of Dutch clay soils according to the PLE boundary values of Reeve et al., but between pressure heads of 0 and $-16000 \mathrm{~cm}$. The resulting classification is presented in Table 5 . 
Table 5. Classification of shrink-swell potential of Dutch clay soils.

\begin{tabular}{lll}
\hline $\begin{array}{l}\text { Shrink-swell } \\
\text { potential }\end{array}$ & $\begin{array}{l}\text { PLE (between } h=0 \\
\text { and } h=-16000 \mathrm{~cm}) \\
(\mathrm{cm})\end{array}$ & Location \\
Low & $<9$ & \\
Moderate & $9-14$ & $\begin{array}{l}\text { Oosterend, Nieuw Statenzijl, } \\
\text { Kats, Schermerhorn, Dronten, } \\
\text { Bruchem }\end{array}$ \\
Large & $>14$ & Nieuw Beerta \\
\hline
\end{tabular}

\section{Conclusions}

Only few shrinkage characteristics of Dutch clay soils resemble the idealized picture of Figure 3. The measured shrinkage characteristics (Fig. 5) vary strongly with respect to magnitude of shrinkage, relation with pressure head values, air entry points, start and end of shrinkage phases etc.

Some heavy clay soils from the Netherlands belong to the strongest swellingshrinking soils of the world, but also relatively light clay soils like Kats and Schermerhorn show considerable shrinkage indicating that even in these soils processes resulting from shrinkage, like bypass flow, may take place. (Fig. 5, Table 2, Table 4).

Volume decrease of Dutch clay soils aggregates that dry from saturation to ovendryness is maximally $49 \%$ (Table 2 ). In the Netherlands because of climatic conditions the range between saturation and a pressure head of $-16000 \mathrm{~cm}$ is of more relevance. In this range the maximum volume decrease of a soil horizon is $42 \%$ (Nieuw Beerta $\mathrm{C} 11 \mathrm{~g}$ ) and the potential surface subsidence of a soil in situ is about $15 \mathrm{~cm}$ (Nieuw Beerta) (Table 2).

Some clay soils in the Netherlands show normal shrinkage from saturation to pressure heads much lower than $-16000 \mathrm{~cm}$ (Fig. 5). This means that in the field, the aggregates of these soils will always remain saturated. Only inter-aggregate pores, which change their dimensions throughout the year, may contain air. This will have consequences for instance for root development and the occurrence of partial anaerobiosis.

\section{Acknowledgements}

We wish to thank Ir A. D. van Vessem for assistance in taking some of the samples. Also the cooperation of the farmers at whose fields we took samples is gratefully acknowledged. Mr K. Oostindie took care of the statistical analysis. 


\section{References}

Berndt, R. J. \& K. J. Coughlan, 1977. The nature of changes in bulk density with water content in a cracking clay. Australian Journal of Soil Research 15: 27-37.

Blake, G. R. \& K. Hartge, 1986. Particle density. In: A. Klute (Ed.), Methods of soil analysis. Part 1: Physical and mineralogical methods, p. 877-382. Soil Science Society of America Inc., Madison, Wisconsin, USA.

Bolt, G. H. \& M. G. M. Bruggenwert (Eds), 1978. Soil chemistry. A: Basic elements. Elsevier, Amsterdam Netherlands, $281 \mathrm{pp}$.

Bouma, J., L. W. Dekker, \& J. C. F. M. Haans, 1979. Drainability of some Dutch clay soils: a case study of soil survey interpretation. Geoderma 22: 193-203.

Brasher, B. R., D. P. Franzmeier, V. Valassis \& S. E. Davidson, 1966. Use of saran resin to coat natural soil clods for bulk-density and water retention measurements. Soil Science 101: 108.

Bronswijk, J. J. B., 1988. Modeling of water balance, cracking and subsidence of clay soils. Journal of Hydrology 97: 199-212.

Bronswijk, J. J. B., 1989. Prediction of actual cracking and subsidence in clay soils. Soil Science 148: 87-93.

Coles, N. \& S. Trudgill, 1985. The movement of nitrate fertilizer from the soil surface to drainage waters by preferential flow in weakly structured soils, Slapton, S. Devon. Agriculture, Ecosystems and Environment 13: 241-259.

Dasog, G. S., D. F. Acton, A. R. Mermuth \& E. de Jong, 1988. Shrink-swell potential and cracking in clay soils of Saskatchewan. Canadian Journal of Soil Science 68: 251-260.

Farbrother, H. G., 1972. Field behaviour of Gezira Clay under irrigation. Cotton Growing Review 49: $1-27$.

Franzmeier, D. P. \& S. J. Ross, 1968. Soil swelling: laboratory measurements and relation to other soil properties. Soil Science Society of America Proceedings 32: 573-577.

Gee, G. W., \& J. W. Bauder, 1986. Particle-size analysis. In: A. Klute (Ed.), Methods of soil analysis. Part 1: Physical and mineralogical methods, p. 383-412. Soil Science Society of America Inc., Madison, Wisconsin, USA.

Gillot, J. E., 1986. Some clay-related problems in engineering geology in North America. Clay Minerals 21: $261-278$.

Green-Kelly, R., 1974. Shrinkage of clay soils: a statistical correlation with other soil properties. Geoderma 11: 243-257.

Grossman, R. B., B. R. Brasher, D. P. Franzmeier \& J. L. Walker, 1968. Linear extensibility as calculated from natural-clod bulk density measurements. Soil Science Society of America Proceedings 32: $570-573$.

Haines, W. B., 1923. The volume changes associated with variations of water content in soil. Journal of Agricultural Science (Cambridge) 13: 296-311.

Jones, D. E. \& W. G. Holtz, 1973. Expansive soils - the hidden disaster. Civil Engineering 43: 49-51.

Leffelaar, P. A., 1987. Dynamics of partial anaerobiosis, denitrification, and water in soil: experiments and simulation. Doctoral thesis. Wageningen Agricultural University, Wageningen, Netherlands, 117 pp.

McCormack, D. E. \& L. P. Wilding, 1975. Soil properties influencing swelling in Canfield and Geeburg soils. Soil Science Society of America Proceedings 39: 496-502.

Miedema, R., 1987. Soil formation, microstructure and physical behaviour of Late Weichselian and Holocene Rhine deposits in the Netherlands. Doctoral thesis. Wageningen Agricultural University, Wageningen, Netherlands, 399 pp.

Murray R. S. \& J. P. Quirk, 1980. Clay-water interactions and the mechanism of soil swelling. Colloids and Surfaces 1: 17-32.

Parker, J. C., D. F. Amos \& D. L. Kaster, 1977. An evaluation of several methods of estimating soil volume change. Soil Science Society of America Journal 41: 1059-1064.

Parker, J. C., D. F. Amos \& L. W. Zelazny, 1982. Water adsorption and swelling of clay minerals in soil systems. Soil Science Society of America Journal 41: 1059-1064.

Reeve, M. J. \& D. G. M. Hall, 1978. Shrinkage of clayey subsoils. Journal of Soil Science 29: 315-323. 


\section{J. J. B. BRONSWIJK AND J. J. EVERS-VERMEER}

Reeve, M. J. \& D. G. M. Hall \& P. Bullock, 1980. The effect of soil composition and environmental factors on the shrinkage of some clayey British soils. Journal of Soil Science 31: 429-442.

Ross, G. J., 1978. Relationships of specific surface area and clay content to shrink swell-potential of soils having different clay mineralogical composition. Canadian Journal Soil Science 58: 159-166.

Schafer, W. M. \& M. J. Singer, 1976. Influence of physical and mineralogical properties on swelling of soils in Yolo County, California. Soil Science Society of America Journal 40: 557-562.

Smith, C. W., A. Hadas, J. Dan \& H. Koyumdjisky, 1985. Shrinkage and Atterberg limits in relation to other properties of principal soil types in Israel. Geoderma 35: 47-65.

Soil Survey Staff, 1975. Soil taxonomy: a basic system for soil classification for making and interpreting soil surveys. Agric. Handbook 436. US Department of Agriculture, Washington, USA, 754 pp.

Stirk, G. B., 1954. Some aspects of soil shrinkage and the effect of cracking upon water entry into the soil. Australian Journal of Agricultural Research 5: 279-290.

Swartz, G. L., 1966. Water entry into a black earth under flooding. Queensland Journal of Agricultural and Animal Science 23: 407-422.

Tessier, D., 1984. Experimental study on organisation of clayey materials (in french). PhD thesis. INRA, Paris, 362 pp.

Thomas, G. W. \& R. E. Phillips, 1979. Consequences of water movement in macropores. Journal of Environmental Quality 8: 149-152.

Wilding, L. P. \& C. T. Hallmark, 1984. Development of structural and microfabric properties in shrinking and swelling clays. In: J. Bouma \& P. A. C. Raats (Eds), Proceedings ISSS Symposium 'Water and solute movement in heavy clay soils'. Publ. 27, International Institute for Land Reclamation and Improvement (ILRI), Wageningen, Netherlands, p. 1-22.

Yule, D. F. \& J. T. Ritchie, 1980. Soil shrinkage relationships of texas vertisols. I. Small cores. Soil Science Society of America Journal 44: 1285-1291. 